\title{
Evaluation of Effect on Housing Prices and User Perceptions of the Urban Environmental Features of Sarıçay and Present Landscape Equipment: The Example of Çanakkale
}

\author{
Yavuz ALKAN ${ }^{1 *}$ \\ ${ }^{1}$ Çanakkale Onsekiz Mart University, Lapseki Vocational High School, Department of Landscape and \\ Ornamental Plants, 17800 Lapseki, Çanakkale
}

\begin{abstract}
This study focused on the economic value of housing and environmental attributes with variability according to demand, for the neighborhood adjoining the Sarıçay River in the Çanakkale urban area. Accordingly, an increasing trend emerged for housing prices linked to environmental attributes and attention was drawn to this share which may be used for sustainable development of the region. A survey based on the hedonic pricing method determined the value of the Sarıçay river, strait view, location and landscape qualities. With the same approach, a survey based on conditional valuation using a model landscape design created with the "Realtime Landscaping Architect 20" program was used to provide an assessment based on the willingness of 400 residents of the region. From the close results obtained with the two methods, the contribution of environmental attributes to housing prices was found to be 88,229 TL. From here, based on sales of 200 houses in the region, nearly $17,564,800 \mathrm{TL}$ social benefit can be mentioned. Additionally, integration and rational management of this benefit by local administrations will make it possible to provide sustainable ideal environmental development (care and maintenance) for the regional public and living areas.
\end{abstract}

Keywords: Housing prices, economic value, hedonic price, conditional valuation method.

\section{Konut Fiyatlarına Etkisi ve Kullanıcı Algıları Doğrultusunda Kentsel Çevre Kalitesinin Sarıçay ve Mevcut Peyzaj Donatıları Kapsamında Değerlendirilmesi: Çanakkale Örneği}

Öz

Çalışmada, konutun sahip olduğu ve talebe göre değişkenlik gösteren çevresel özniteliklerin ekonomik değerleri Çanakkale kentselinde Sarıçay Kanalına komşu mahallelerde mercek altına alınmıştır. Buna göre, artış trendinde olan konut fiyatlarının çevresel özniteliklere bağlı olarak gerçekleştiği ve bu payın bölgenin sürdürülebilir gelişmesinde kullanılabileceğine dikkat çekilmiştir. Hedonik pricing yöntemi esasına göre yapılan anket uygulamasıyla Sarıçay kanalının, Boğaz manzarasının, konum ve peyzaj kalitesinin değerleri belirlenmiştir. Aynı yaklaşımla bölge için Realtime Landscaping Architect 20 programında oluşturulan model peyzaj tasarımı kullanılarak Koşullu Değerlendirmeye göre uygulanan anketle de 400 bölge sakininin gönüllülük esasına dayalı değerlendirmelerine ulaşılmıştır. İki yöntemle elde edilen yakın sonuçlardan çevresel özniteliklerin konut fiyatına katkısı ortalama 88.229 TL bulunmuştur. Buradan bölgede satışı gerçekleşen 200 konut için yaklaşık 17.645.800 TL toplumsal faydadan söz edilebilir. Bununla birlikte faydanın yerel yönetime entegrasyonu ve rasyonel yönetilmesi ile bölge halkı ve yaşam alanları açısından sürdürülebilir ideal çevre gelişimlerinin (bakım ve onarımlarının) sağlanması mümkün olabilecektir.

Anahtar Kelimeler: Konut fiyatları, ekonomik değer, hedonik fiyat, koşullu değerleme yöntemi.

\footnotetext{
*Corresponding Author (Sorumlu Yazar):

Yavuz ALKAN (Assist. Prof. Dr.); Çanakkale Onsekiz Mart University, Lapseki 


\section{Introduction}

Whether environmental factors preserving their natural form like climate, water resources, soil, natural plant cover and topography, or expertly planned landscaping and equipment, they do not have economic value directly in their current state or in any legal procedure (Makinde, 2013). However, in the free market and especially in practice, assets like housing, workplaces and land have added monetary value according to their proximity to these features (Schaerer et al. 2008). Currently, especially in urban areas, housing prices display significant differences and variability according to environmental features in terms of nature and culture (Alas, 2020; Alkan and Uslu, 2016; Demircan and Oğuztimur, 2019). In this situation, non-taxable income is created from housing. Determination of the market value of this income specific to environmental features and inclusion in housing tax will have an important place at the point of developing and improving environmental features, managing care and maintenance and increasing quality of life for urban-dwellers by making more rational investments in the urban texture (Hur and Marrow-Jones, 2008). With this aim, research was planned to inquire about the present housing market along the riverbed of the Sarıçay in Çanakkale province from real estate agents and public inquiries using a survey application. Firstly, neighborhoods bounding the study area of the Sarıçay were determined. Accordingly, the Barbaros, Namık Kemal and İsmetpaşa neighborhoods representing the boundary to the Sariçay and comprising standard housing material with intense sales potential formed the study material. The features of the standard housing type were determined as $85-100 \mathrm{~m}^{2}$ and 2 bedrooms +1 living room. The plan was to determine the mean prices of standard housing along the banks of the Sariçay with and without environmental features. Within the scope of environmental features, open and green spaces included neighborhood parks, children's playgrounds and sports areas; view features including views of the straits, river and urban area; and location features including position of the housing on boulevards, avenues and streets. The economic values of standard housing related to these characteristics were obtained within the scope of public perceptions and real estate agents (Ergöz Karahan, 2017). In the first stage completed within the scope of the hedonic pricing method, 20 real estate agents within the research area were reached and the plan was to determine minimum and maximum sales values for standard housing in 2019 (Goodman and Thibodeau 2003). Additionally, the rate of reflection of environmental features in housing prices; in other words, the increasing effect of environmental features on housing prices (benefits), were determined in this stage (Freeman, 1979). In the second stage, a survey application was performed with the aim of determining the economic correlation between environmental factors and housing prices through data from 400 surveys (Pulido, 1972). In this section, the attitudes of individuals to environmental features and environmental feature-housing correlations were researched. In this stage, model design plans and perspective appearance of environmental features and housing variables were used. The data obtained for each quality in terms of benefit to housing prices for housing with these environmental features (green space, view, location) were finalized with mean values. Also, participants were asked about how much they thought being very close, close, a little close, distant and very distant from each type of green space (neighborhood park, children's playground, sports area) independent of each other (only considering the stated type) would increase the price of housing they considered buying (Willis and Garrod,1991; Likert, 1932; Kyttä et al. 2011). In conclusion, the basic aim of the study was to determine the economic value of environmental features. This reveals the economic contribution of these environmental features to housing prices (Olanrewaju and Wong, 2020; Des Rosiers et al. 2002). It is important at this stage to confirm that the hedonic pricing and conditional valuation methods overlap (Gürlük and Rehber, 2009). As a result, the basis of this study is to reveal the benefits provided to housing prices by environmental features and provide legal status for this income and thus to transform this into local and national gains (Yılmaz and Koç, 2018). Additionally, targets included the inclusion of these gains for development of environmental features and for care and maintenance activities. Survey data about housing prices and environmental features had regression analysis planned with the SPSS 15.0 statistical program. Thus, statistical correlations between housing and environmental features would be determined. Here, it was concluded that the model revealed by the analysis within the scope of the study was largely significant. The desired results of this research include to research price variations for housing along the banks of the Sarıçay in the situation of developed planning and design in relation to the current status and expectations for the Sarıçay with great importance in Çanakkale and to reveal the value of unearned income of housing owners and thus to include this unearned income in local and national income on a legal basis. This study may be assessed as a new study. Just as in similar studies, "do environmental features within the scope of landscape possibilities and equipment of the Sarıçay have a positive effect on housing prices located along the Sarıçay?" Attempts were made to answer this hypothesis. It is predicted that the place and importance of conditional valuation and hedonic pricing methods to determine the economic value of environmental features without market value will be further emphasized in the literature. (Soguel et al. 2007). This study focuses on the emergence of unearned income shares becoming more pronounced in some specific locations linked to urban development in proportion to the increase in housing prices (Alkan Gökler, 2017), transferring this potential financial resource to local administrators and assessing rational environmental planning with approaches positively affecting quality of life. The study focused on the area close to the Sarıçay river channel in Çanakkale. 
The study was founded on the assumption that determining the reflection of factors like green spaces (neighborhood parks, children's playgrounds and sports areas), landscaping/views (straits, town and river views) and street/avenue/boulevard in housing prices in real terms and transferring this to municipal councils as 'ecologic/environmental added tax' would increase the quality of life of individuals in the region and positively contribute to ecologic development (Salihoğlu and Türkoğlu, 2019). Hedonic pricing using current housing prices in sales on the real estate market and contingent valuation using the housing prices volunteered by individuals from initiatives in the region were determined in this research with differences in housing prices linked to location in terms of environmental variables. In conclusion, attention is drawn to the reality that the contribution level to the development of the region by local administrations will reach very significant dimensions in the scenario where the financial potential revealed by the price differences in this research are transferred to municipal councils.

\section{Material and Methods}

\subsection{Study area}

The study area comprises Sarıçay and surroundings in Çanakkale city located geographically between

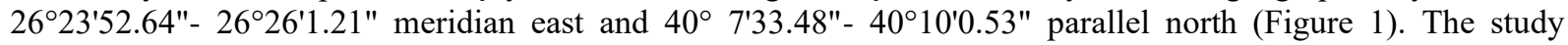
focused on the environmental features of Sarıçay and the housing prices around the Sarıçay. The initial stage of the study determined the standard housing type. Accordingly, the study determined that the standard housing type around the Sarıçay with intense sales rates was $85-100 \mathrm{~m}^{2}$ and 2 bedrooms +1 living room.
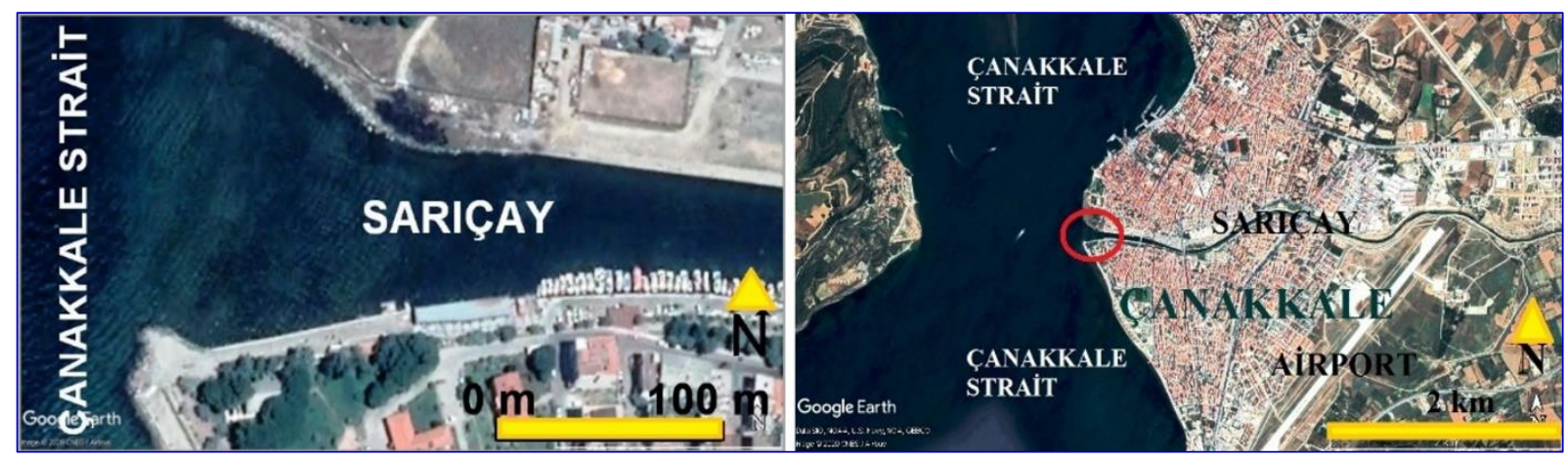

Figure 1. Geographic location and current status of the working area, obtained from Google Earth 2020.

\subsection{Methodology}

The study was evaluated in 4 stages.

\section{First stage:}

Within the scope of the hedonic pricing method, a survey was applied about standard 200 housing located in Barbaros, Namık Kemal and İsmetpaşa neighborhoods to a total of 20 real estate agents in these neighborhoods to determine the prices of housing with and without environmental features. The survey application asked each real estate agent about housing prices with sales completed, and how much value was added by environmental features. Here, pricing of environmental features was determined.

\section{Second stage:}

The second survey application was performed within the scope of the conditional valuation method. For this, 400 individuals aged from 20-60 years in the research area were randomly interviewed face-to-face. To determine the sample number, a minimum 400 subjection recommendation for a settlement of 100,000 population was noted with Arkin and Colton's 5\% error margin. Within the scope of the survey, importance levels attached by participants to the environmental features (open and green spaces/neighborhood parks, children's playgrounds and sports areas; view/straits, river and city; location/boulevard, avenue and street) of housing were determined as percentages. During this determination, model designs representing environmental features and housing were used in the computer environment by loading images of the study area from Google Earth (2020) to the Realtime Landscaping Architect program (Fig.2). Moving from here, participants were asked to determine two different prices for standard housing. The first price had the condition of standard housing without environmental features, while the second price had the condition of having all environmental features. 


\section{Third stage:}

Within the scope of conditional valuation, attempts were made to determine the monetary value participants were willing to pay according to the proximity to the environmental features. Here, the plan was to confirm the results of hedonic pricing in the previous stage with the results obtained from the conditional valuation method. The survey application inquired about the housing prices that participants considered buying under assumed market conditions, the economic value added by environmental features, and the economic value that participants were willing to pay for the added economic value according to proximity of housing to the environmental features.

\section{Fourth stage:}

The survey data were transferred to the SPSS 15.0 program for statistical analysis. A regression model was used to determine the significance of correlations between the dependent variable (standard housing price without environmental features) and the independent variables (economic value participants were willing to pay for environmental features). These correlations are summarized in tables and interpreted. Additionally, emphasis was placed on the socioeconomic structure among survey participants at this point.

\section{Results}

In this study focusing on determination of prices for standard housing and adjacent environmental features along the axis of the Sarıçay, firstly 400 surveys were applied within the scope of the 'conditional valuation method'. The survey study questioned participants about housing prices they considered under assumed market conditions and the economic value added by environmental features. In this process, pricing was determined based on the distances between the environmental features and the housing. With the aim of obtaining clearer and healthy data from public questioning with the survey study, the model landscape design pattern included in Figure 2 was used. In the design created by transferring the plan appearance of the study area in Google Earth into a direct technical drawing environment, the inclusion of a planting legend was effective on rational reflection of public perception in the survey data (Figure 2).

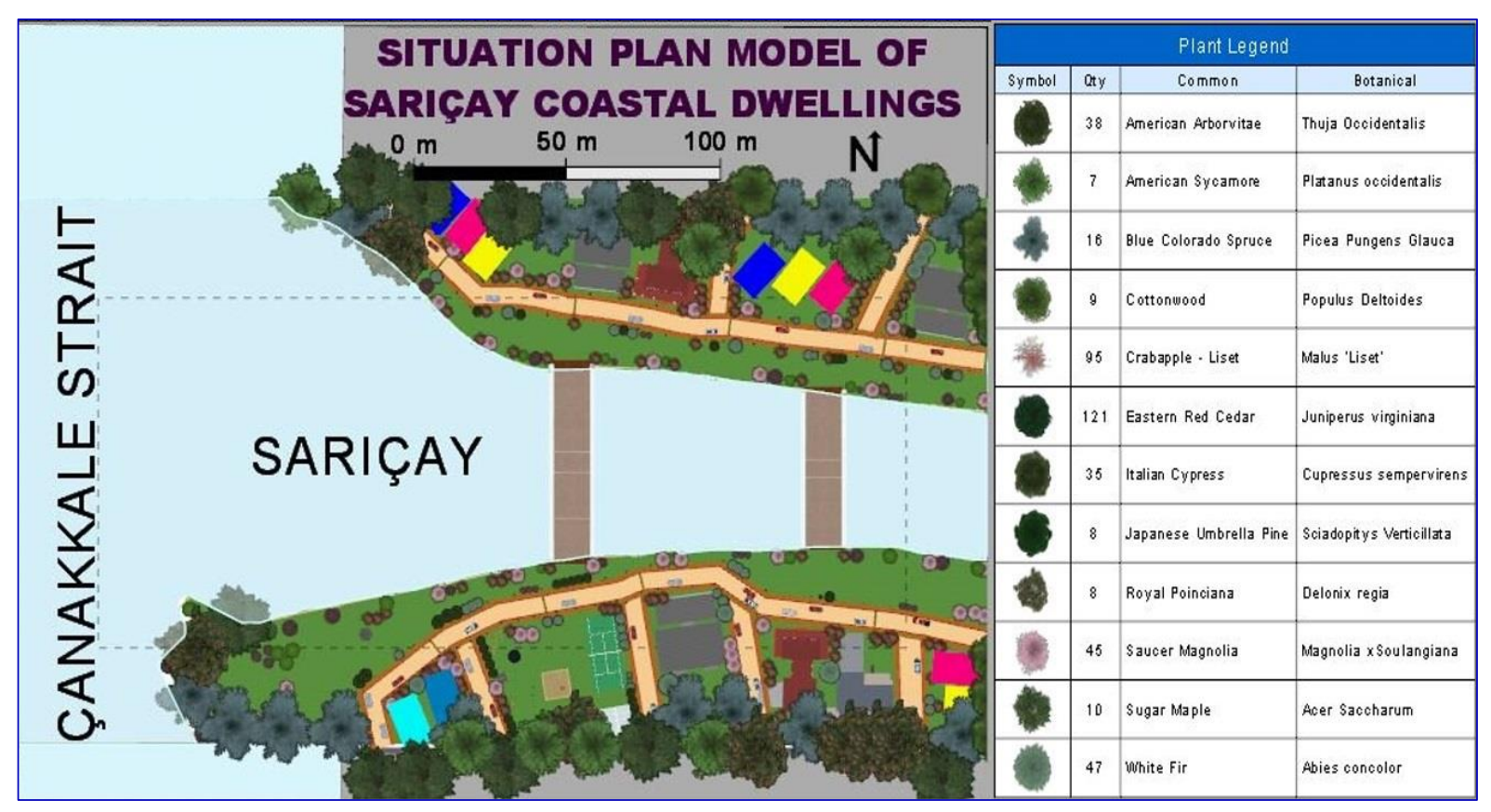

Figure 2. Plan appearance of model landscape design planned for planting and structural landscape patterns.

Within the scope of developing the current planting structure, plant species of eastern white cedar 38 plants (Thuja occidentalis), American sycamore 7 plants (Platanus occidentalis), blue spruce 16 plants (Picea pungens glauca), necklace poplar 9 plants (Populus deltoides), crabapple 95 plants (Malus liset), eastern juniper 121 plants (Juniperus virginiana), Mediterranean cypress 36 plants (Cupressus sempervirens), Japanese umbrella pine 8 plants (Sciadopitys verticillata), flame tree 8 plants (Delonix regia), magnolia 45 plants (Magnolia $x$ soulangeana), sugar maple 10 plants (Acer saccharum), and white fir 47 plants (Abies concolor) were included in the design in the stated amounts. According to survey results, it was concluded that the sections of the Sarıçay close to the straits did not have effective structure in terms of esthetics and functions. A model landscape design 
pattern was obtained to resolve the deficient aspects of the present cultural landscaping structure, as seen in Figure 3.

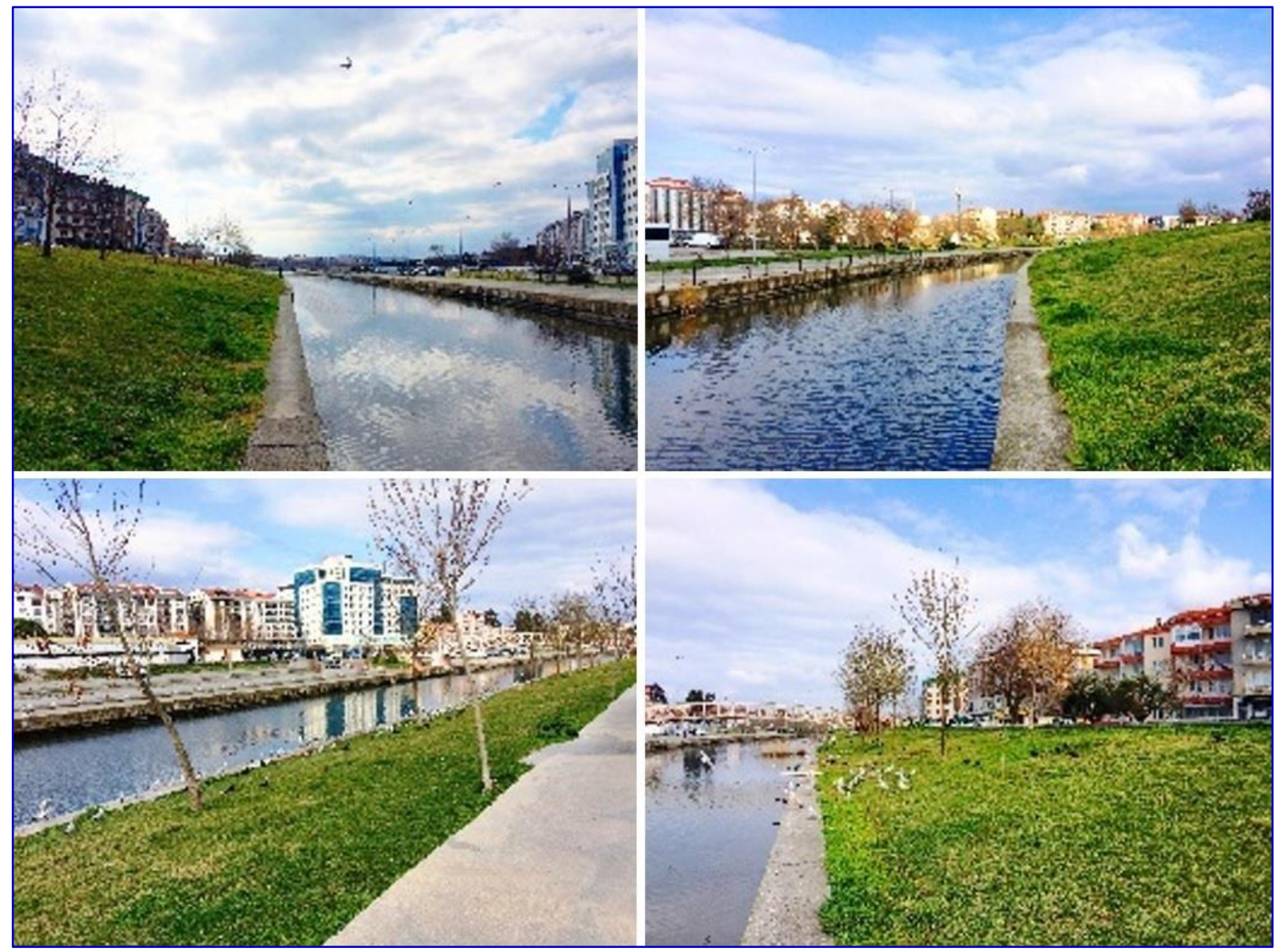

Figure 3. Visuals of the present riverbank landscape patterns along the Sarıçay.

The first perspective appearance obtained in the model design in Figure 4 includes an image taken from east-west perspective, while the other has west-east perspective images. The landscape patterns in visuals were effective in obtaining healthier public perceptions.

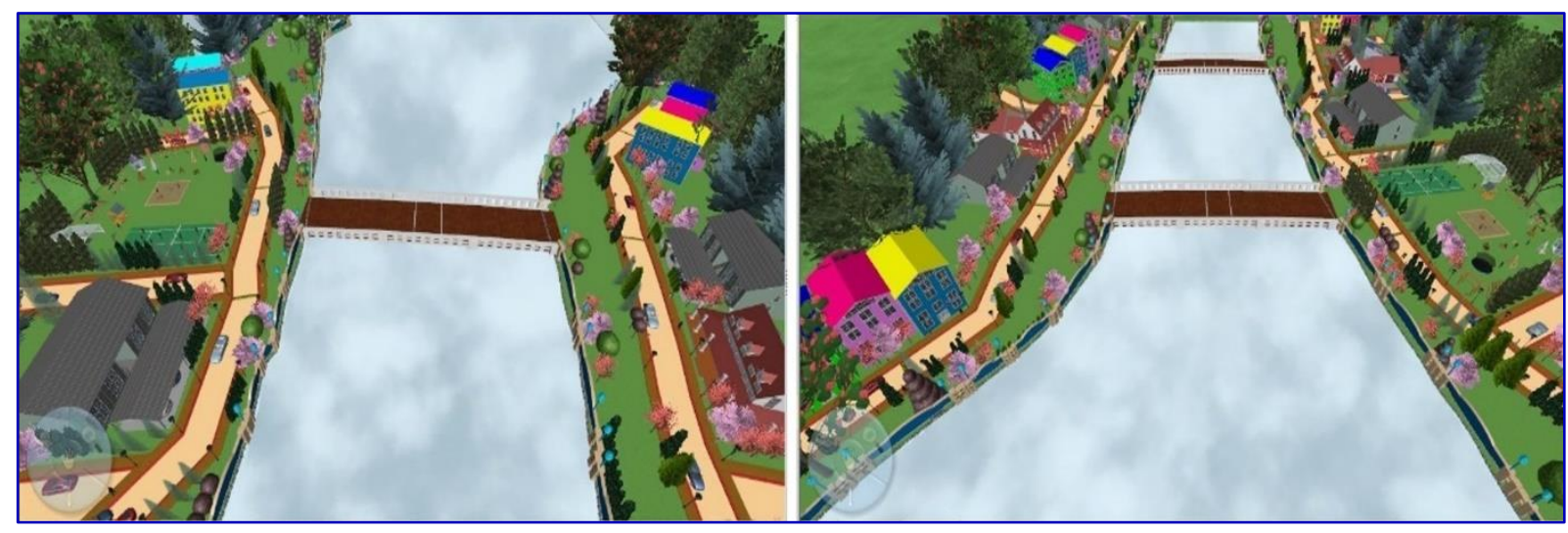

Figure 4. Perspective appearances obtained from model landscape design from different aspects.

The perspective appearances of the north and south banks of the river within the designed model landscape pattern adapted to the study area are shown below (Figure 5). 

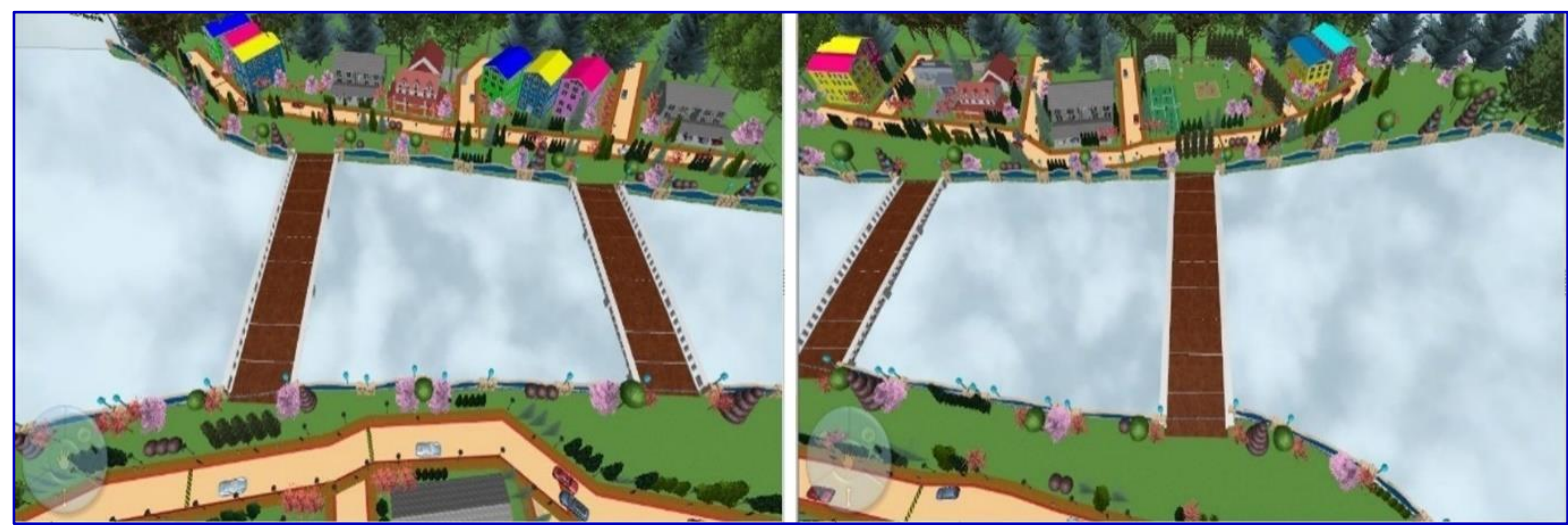

Figure 5. Perspective appearance of model landscape design obtained from north and south riverbanks.

The amounts that individuals were willing to pay according to the proximity of housing to open and green space areas of neighborhood parks, children's playgrounds and sports areas, assessed within the scope of the conditional valuation method in the study, are given in Figure 6. According to the figure, sports areas had highest premium, with least payment share determined for use as neighborhood parks.

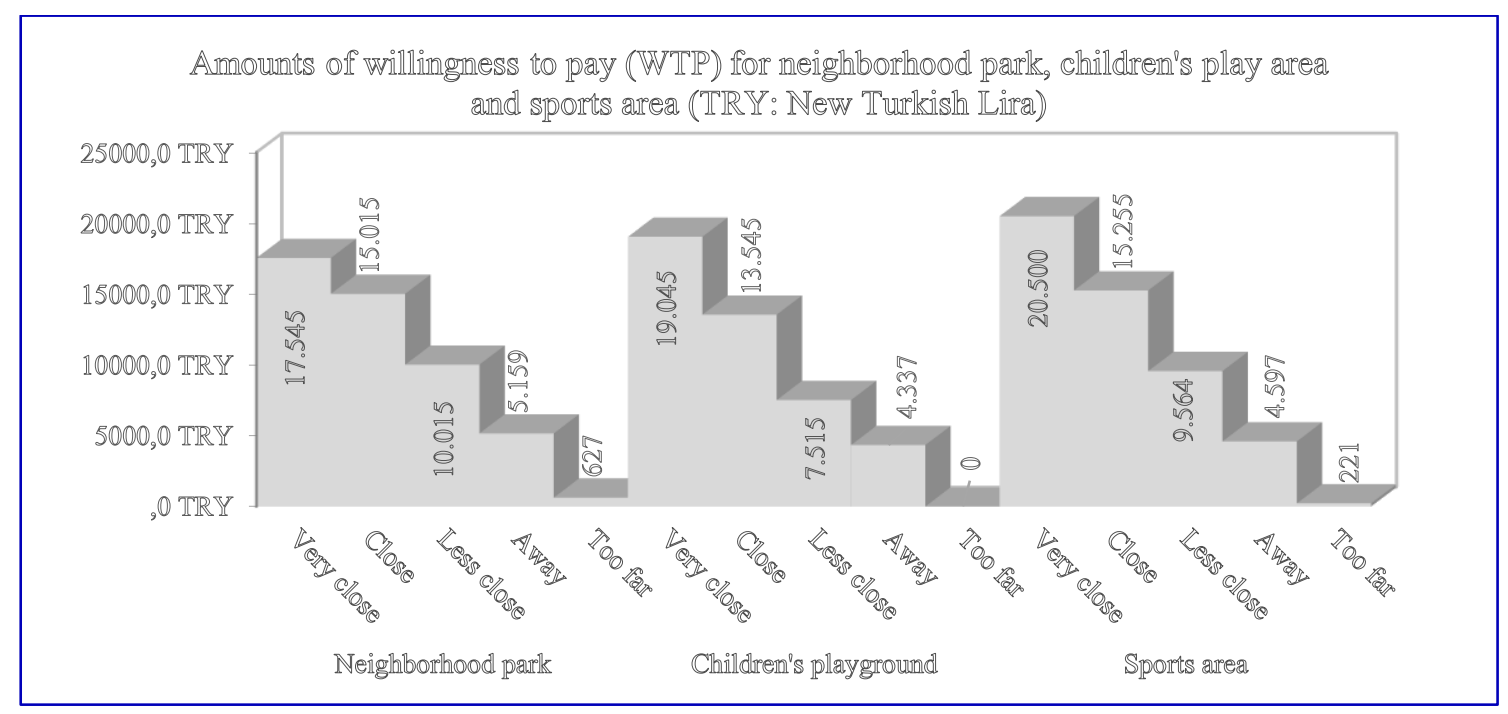

Figure 6. Individual payment desire according to proximity of housing to neighborhood parks, children's playgrounds and sports area equipment within the scope of conditional valuation.

The survey applied in the second method in the study of 'hedonic pricing' targeted 20 real estate agents with institutional structure and high sales potential. The survey application questioned each real estate agent about housing prices (10 standard housing) for sales completed in recent times, and how much economic value was added by environmental features. According to sales data obtained from real estate agents for the end of 2019 included in Table 1, the total economic value of environmental features on current sales prices completed for the standard housing concept was concluded to be equivalent to nearly $50 \%$ of the price of houses without these features. As a result, while standard 2+1 housing without environmental features was sold for 252,290 TRY, the price with environmental features was observed to be mean 344,350 TRY. It was revealed that the 92,060 TRY difference belonged to environmental features. In conclusion the 'unearned income value' of the present landscape pattern can be mentioned. Similarly, for other housing sales examples, it may be concluded that $50 \%$ of the economic value is the share for environmental features. As a result of the survey based on Conditional Valuation, the contribution of environmental qualifications to housing was found at 84,398 TRY. It is remarkable that the result is close to the Hedonic Pricing Method result. 
Table 1. Minimum and maximum average standard housing sales prices in 2019 according to Çanakkale real estate agents.

\begin{tabular}{|c|c|c|c|c|c|c|c|c|c|c|}
\hline $\begin{array}{l}\text { Housing } \\
\text { standard }\end{array}$ & $\begin{array}{l}\text { Building } \\
\text { age }\end{array}$ & $\begin{array}{l}\text { Gross } \\
\left(\mathbf{m}^{2}\right)\end{array}$ & Floor & Landscape & $\begin{array}{l}\text { Open } \\
\text { and } \\
\text { green } \\
\text { area }\end{array}$ & Location & $\begin{array}{l}\text { Average } \\
\text { price } \\
\text { (TRY) } \\
\text { HPM }\end{array}$ & $\begin{array}{l}\text { Increase } \\
\text { (TRY) } \\
\text { HPM }\end{array}$ & $\begin{array}{l}\text { Average } \\
\text { price } \\
\text { (TRY) } \\
\text { CVM }\end{array}$ & $\begin{array}{l}\text { Increase } \\
\text { (TRY) } \\
\text { CVM }\end{array}$ \\
\hline $\begin{array}{l}2 \text { Rooms, } \\
1 \text { living } \\
\text { room, } \\
\text { indoor } \\
\text { kitchen } \\
\end{array}$ & $5 / 10$ & $85-100$ & $\begin{array}{l}\text { Intermediate } \\
\text { floor }\end{array}$ & $\begin{array}{l}\text { Bosphorus } \\
\text { \&Sarıçay } \\
\text { canal }\end{array}$ & Current & $\begin{array}{l}\text { Street, on } \\
\text { the } \\
\text { Boulevard }\end{array}$ & 344,350 & $\% 36$ & 257,058 & $\% 49$ \\
\hline $\begin{array}{l}2 \text { Rooms, } \\
1 \text { living } \\
\text { room, } \\
\text { indoor } \\
\text { kitchen }\end{array}$ & $5 / 10$ & $85-100$ & & $\overline{\text { City }}$ & No & $\begin{array}{l}\text { Interme- } \\
\text { diate road }\end{array}$ & 252,290 & 92,060 & 172,660 & 84,398 \\
\hline
\end{tabular}

This study applied methods in an attempt to explain the current situation of the public by focusing on providing a certain economic value based on a priority condition and orientation toward a hedonic or enjoyment-linked lifestyle in pricing environmental goods. As stated in Table 2, it was revealed that both methods confirmed each other as very close values were found with both methods in terms of the economic amount of value for environmental features.

Table 2. Economic value added to standard housing prices by subtypes of environmental features within the scope of conditional valuation and hedonic pricing methods.

\begin{tabular}{|c|c|c|c|c|c|}
\hline \multicolumn{2}{|c|}{$\begin{array}{l}\text { Environmental } \\
\text { Qualifications }\end{array}$} & \multirow{2}{*}{$\begin{array}{l}\begin{array}{l}\text { Hedonic Price } \\
\text { Method (TRY) }\end{array} \\
16,364\end{array}$} & \multirow{2}{*}{$\begin{array}{l}\text { TRY } \\
39,306\end{array}$} & \multirow{2}{*}{$\begin{array}{l}\text { Conditional Valuation } \\
\text { Method (TRY) } \\
16,754\end{array}$} & \multirow{2}{*}{$\begin{array}{l}\text { TRY } \\
37,831\end{array}$} \\
\hline Green & Neighborhood park & & & & \\
\hline & Children's playgrounds & 12,653 & & 11,131 & \\
\hline & Sports Area & 10,289 & & 9,946 & \\
\hline & Bosphorus & 12,326 & 28,694 & 9,885 & 25,386 \\
\hline \multirow[t]{3}{*}{ Views } & Canal & 8,763 & & 7,707 & \\
\hline & City & 7,605 & & 7,794 & \\
\hline & Boulevard & 9,979 & 24,060 & 9,122 & 21,181 \\
\hline \multirow[t]{2}{*}{ Location } & Street & 7,704 & & 6,118 & \\
\hline & Intermediate Road & 6,376 & & 5,940 & \\
\hline
\end{tabular}

The findings for regression analysis results of survey data based on the conditional and hedonic methods are given below. The coefficients and significance values for the regression model are given in Table 3 . The fixed term coefficients were calculated as 221,287 and 264,299 and the p values usually were between 1 and $10 \%$. This situation indicates the fixed terms are significant. Collinearity statistics (VIF values) were not calculated as 3 and above, so there was no correlation between independent variables and it was interpreted that all variables were appropriate to remain in the model. In other words, this situation indicates there is no multiple linearity problem, which is important in terms of meeting expectations (Table 3). 
Table 3. Economic value added to standard housing prices by subtypes of environmental features within the scope of conditional valuation and hedonic pricing methods.

\begin{tabular}{|c|c|c|c|c|c|c|c|c|}
\hline & \multicolumn{4}{|c|}{ Coefficients(a) } & & & \multicolumn{2}{|c|}{ Correlations } \\
\hline & $\begin{array}{l}\text { Unstandardized } \\
\text { Coefficients } \\
\text { B (CVM) } \\
\end{array}$ & $\begin{array}{l}\text { Unstandardized } \\
\text { Coefficients } \\
\text { B (HPM) } \\
\end{array}$ & Sig.CVM & Sig.HPM & $\begin{array}{l}\text { VIF } \\
\text { (CVM) }\end{array}$ & $\begin{array}{l}\text { VIF } \\
\text { (HPM) }\end{array}$ & CVM & HPM \\
\hline (Constant) & 221,287 & 264,299 & 0.000 & 0.000 & & & 1.000 & 1.000 \\
\hline Neigborhood_park & -0.823 & 1.254 & 0.000 & 0.004 & 1.265 & 1.170 & -0.336 & 0.247 \\
\hline Childrens_playground & -0.509 & -0.391 & 0.024 & 0.000 & 1.502 & 1.315 & -0.299 & -0.184 \\
\hline Sports_area & -0.607 & -0.077 & 0.006 & 0.856 & 1.359 & 1.297 & -0.276 & -0.010 \\
\hline Bosphorus & -0.861 & -0.365 & 0.000 & 0.214 & 1.263 & 1.633 & -0.258 & -0.356 \\
\hline Canal & -0.332 & -0.678 & 0.175 & 0.000 & 1.366 & 1.809 & -0.187 & -0.343 \\
\hline City & -0.598 & -0.875 & 0.008 & 0.087 & 1.117 & 2.342 & -0.167 & -0.416 \\
\hline Boulevard & 0.126 & -0.043 & 0.598 & 0.921 & 1.296 & 1.676 & -0.076 & -0.272 \\
\hline Street & -1.115 & -0.764 & 0.007 & 0.067 & 1.523 & 1.561 & -0.175 & -0.276 \\
\hline Intermediate Road & -0.291 & -0.531 & 0.435 & 0.315 & 1.438 & 1.828 & -0.133 & -0.269 \\
\hline
\end{tabular}

Dependent Variable: Minimum_price

For multiple regression, the adjusted $\mathrm{R}^{2}$ values should be noted. This value was calculated to have values between 0.240 and 0.260 . In other words, this means the independent variables explain nearly $25 \%$ of the variation in the dependent variable. This value is close to average and satisfactory. At this point, the DurbinWatson statistic was calculated as nearly ' 2 '. This value is an indicator that there is no autocorrelation in the model. The ANOVA test had $\mathrm{p}$ values calculated as 0.000 and it was concluded that there were significant correlations between variables according to both methods (Table 4).

Table 4. Analysis results of survey data within the scope of conditional valuation and hedonic pricing methods.

\begin{tabular}{|c|c|c|c|c|c|c|}
\hline \multicolumn{7}{|c|}{ Model Summary(b) } \\
\hline \multirow{2}{*}{ Model } & \multirow{2}{*}{$\mathbf{R}$} & \multirow{2}{*}{ R Square } & \multirow{2}{*}{$\begin{array}{l}\text { Adjusted } \\
\text { R Square }\end{array}$} & \multicolumn{2}{|c|}{$\operatorname{ANOVA}(\mathbf{b})$} & \multirow[b]{2}{*}{ Durbin-Watson } \\
\hline & & & & $\mathbf{F}$ & Sig. & \\
\hline $\mathrm{CVM}$ & 0.524 & 0.275 & 0.258 & 16.424 & 0.000 & 1.447 \\
\hline HPM & 0.531 & 0.282 & 0.248 & 8.311 & 0.000 & 1.798 \\
\hline \multicolumn{7}{|c|}{ CVM: Conditional Valuation Method; HPM: Hedonic Price Method } \\
\hline $\mathrm{a}$ & \multicolumn{6}{|c|}{$\begin{array}{l}\text { Predictors: (Constant), İntermediate Road, Neighborhood_park, Canal, Childrens_playground, Sports_area, Bosphorus, } \\
\text { Street, Boulevard, City }\end{array}$} \\
\hline b & \multicolumn{6}{|c|}{ Dependent Variable: Minimum_Price } \\
\hline
\end{tabular}

Within the scope of the conditional valuation method, the socioeconomic and demographic structure of housing residents who participated in the survey are given in Figure 7. In terms of socioeconomic status, it is understood individuals had income between 3000-5000 TL. Most were observed to be married. At the same time, it was concluded the educational level of individuals participating in the survey was high school graduate (Figure 7). 


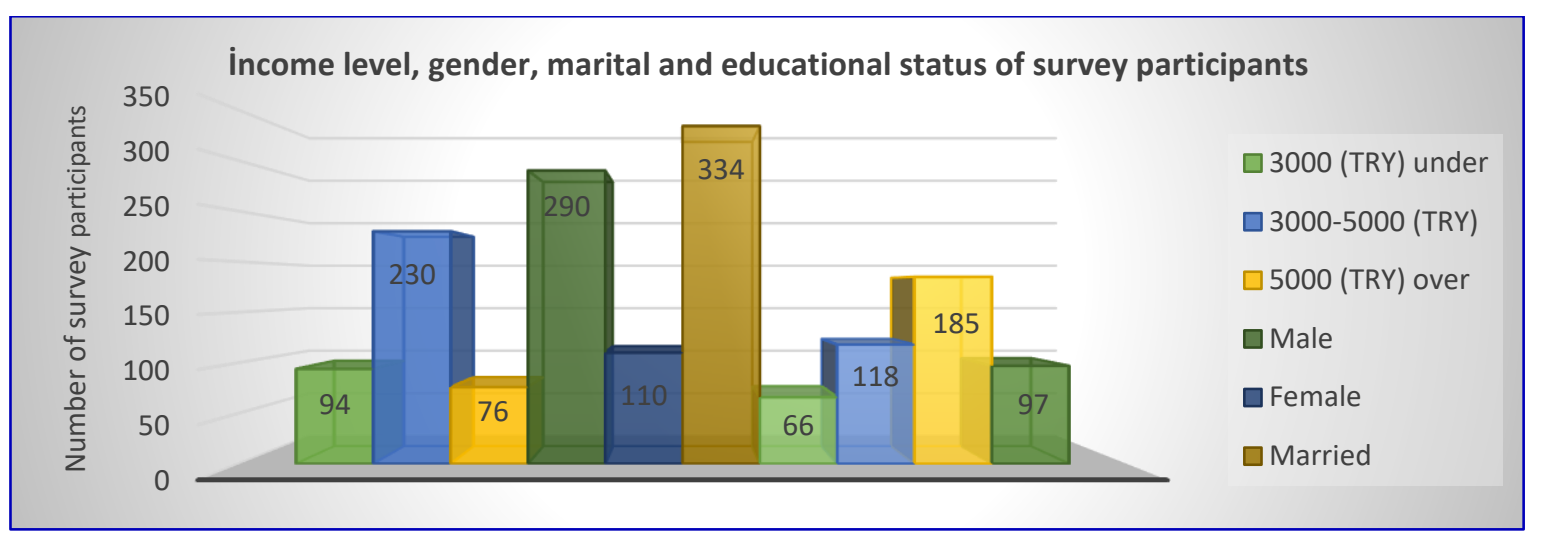

Figure 7. Distribution of survey participants according to gender, marital status, education and income level.

\section{Discussion and Conclusion}

Üre formaldehit tutkalı ile OSB levha üretiminde değişik oranlarda silan muamelesinin levhaların fiziksel ve mekanik özelliklerini farklı şekilde etkilediği belirlenmiştir. Silan muamelesi fiziksel özelliklerinden su alma ve kalınlığına şişme özelliklerini iyileştirmiştir. Kontrol örneğinle kıyaslandığında 2, 24 ve 72 saatlik su alma değerlerindeki azalmaların ortalaması $\% 1, \% 2$ ve $\% 3$ silan kullanımında sirasıla \%8,5, \%11,4 ve \%12,5 olurken, kalınlığına şişmedeki ortalama azalma ise sırasıyla In this study, qualitative and quantitative approaches were used to evaluate the Sarıçay riverbank landscaping (Conditional Valuation and Hedonic Pricing methods were used for this.), targeting important gains for the region by providing a perspective for the future. One of the methods emerging for determination of the value of environmental factors without commercial value is the 'conditional valuation method'. We see that housing prices are configured linked to this value. In this study to determine prices focused on housing within the Sarıçay riverbank landscape pattern in Çanakkale, common or contradictory aspects were revealed with in other similar survey administration and literature studies. Similar correlations between housing prices and location linked to avenue and street variables were revealed in the study by Alas (2020). The article attempted to create a database revealing the implicit monetary value of environmental features and prices of 200 houses in Çanakkale (Montero et al. 2018). Estimations for housing prices were obtained using the hedonic model from traditional and attribute aspects. The study was found to be effective in economic assessment of the accessible environmental qualities of housing. Additionally, green space, views and location parameters were positively reflected in housing prices.

\section{Within the Scope of the Method}

Wong, Susilawati, Miller and Mardiasmo (2020) mentioned that real estate agents in the housing market did not share sustainable jurisprudence relating to housing with clients; as a result, clients were deficient at the point of being conscious housing owners. At the same time, they mentioned the reality that this situation was effective in real estate agents making richer sales for the purpose of unearned income. A similar structure to the one in this study was revealed in the study by Qiu, Tu and Zhao (2019). The study by Mínguez et al. (2013) targeted determination of the implicit amount in housing prices due to the air component among environmental factors, resembling the unique structure of this study. The association is similar for the hedonic pricing theory. As confirmed by statistical data, the results of both studies clearly support the value of environmental attributes (Montero-Lorenzo et al. 2009). Superior qualities of housing in line with environmental qualities/green space, roads and views/landscaping components linked to location increased housing prices confirming the hypothesis of the study as determined in empirical implementations in the study. From the study findings, the hedonic pricing implementation had mean 92,060 TL increase in housing prices within the scope of superior features. However, the contingent valuation implementation was based on volunteering of individuals and similarly there was an 84,398 TL increase in housing prices with identification of the price they were willing to pay. These results show that integration and rational management of this income (mean 88,229 TL per house) into local administration will make it possible to provide sustainable ideal environmental development (care and maintenance) in terms of the regional public and living spaces. (Vlahov et al. 2011; Turcotte and Geiser 2010).

\section{Within the Scope of the Statistical Analysis}

Similar to this study, Gefenaite and al. (2020) included statistical analysis of housing attainability and life 
activities. They found significant results at the 5\% significance level between parameters. Similarly, Zhang and Qiu (2019) determined the use behavior for rural areas with increasing elderly population and emphasized the importance of rural areas for the elderly. They used observation and mapping methods related to behavior. They concluded that recognizable and accessible spaces with few limitations had an encouraging role for use by the elderly. Gür and Murat (2019) in studies targeting determination of positive aspects of user perceptions for the physical conditions of housing, housing areas and neighborhoods analyzed satisfaction in neighborhood examples where high-income residents lived. The importance of the housing parameter for user satisfaction was notable. Housing area and neighborhood satisfaction followed in that order. As a result, it was emphasized that welfare/quality of life increased linked to satisfaction.

\section{In Terms of Similarity to the Fiction of This Study}

The study by Bican (2019) revealing the deficient aspects of available mass housing is important in terms of having common aspects with the structural environment determining deficient equipment in this study. Turk (2019) compared low-quality suburban housing in the İstanbul and Copenhagen examples. Urban welfare degree was determined linked to meeting of needs. It was concluded that providing budgets from a combination of municipal and private section sources was more suitable for formation of an appropriate structural environment. This study emphasized the need for local administration and central administration to act in cooperation. A study by Sarı and Khurami (2018) noted that it was important that housing meet income and living conditions. The need to ensure low income groups were housing owners with necessary legal regulations was noted. In this study, the need for legal regulations to undertake an effective role in including open and green space-housing proportions in the structural form was mentioned. Similarly, a study by Czischke and Bortel (2018) mentioned the effect of environmental factors on valuation of housing prices. Yao et al. (2012) aimed to reveal the user perception of rural landscape values. This study was constructed with similar structure; however, our study was based on urban landscape equipment, while the study by Yao et al. (2012) assessed rural landscape elements. The use of similar statistical analysis methods and similar results are important in terms of showing parallels between the two studies. Ozkan (2014) in a study of forestry texture along both coasts of the İstanbul Bosporus aimed to reveal visual quality with the perception approach. They used representative pictures of the area for observer selections. In this study, model landscape design was used for user perceptions. The results of analysis of data found a linear correlation between texture and quality, clarifying the shared points of the two studies. Studies by Chen, Xu and Devereux (2015) found landscape equipment held an important place in the personal and social experiences of individuals. This study based on determining landscape patterns formed by planting and structural elements by public selection has similar configuration to our study. Soguel et al. (2008) in a study focusing on implicit estimation of the natural landscape pattern in prices chose tourists and area residents as the sample. This study displays differences in terms of determination of the implicit price of cultural landscaping and the inclusion of only town residents as the sample. Both studies emphasized that housing prices may rise linked to the landscaping quality.

\section{Political and Administrative Results}

The laws and regulations about the landscape planning process in Turkey develop under the initiative of architects and urban planners. However, for this process with a very broad range, it is unavoidable that management and planning occur with modern approaches requiring a variety of expert participation including the tourism and ecological dimensions at national, regional and local level (Altan, 2004). Sustainability of landscapes, an important component of people's surroundings, an expression of the diversity of cultural and natural heritage they share and identities, is only possible with multiparticipant administrative tools and legal legislation. The political and administrative implications which can be obtained based on the results of this study are mentioned below. The implication of the need to link the environmental attributes of housing within the scope of 'income tax' and standardization within a defined framework as planning and policy support tools for urban sustainability emphasizes the importance of the study (Gouda and Masoumi 2018; Hewings et al. 2004; Payaslı Oğuz and Aksulu 2016). For this reason, this study has the quality of being a reference for new norms and revision of legal requirements. The social benefit reached in the study is predicted for use in prospective strong actions like developing, restoring or creating landscaping (APS 2003). General principles, strategies and guidelines should be determined in line with the aims of protection, management and planning for environmental attributes or landscaping belonging to housing by competent local and public authorities (Çelik, 2018). Similarly, the study by Alphan (2017) indicated that Mediterranean coastal appearance was exposed to changes with human interventions. Markers of these variations were important for making administrative decisions. This study is a guide for research based on qualitative and quantitative observations to reveal these markers. As a result, the target was to make important projections for decision-makers by dealing with current time and space concept in the structure of the coastline landscaping (Mukhtar et al. 2017; Nayim, 2014). A study by Rimal et al. (2019) 
mentioned rationalizing planning and policies for landscaping dynamics within the scope of sustainable urbanization. Revealing urban development projections on this platform overlaps with approaches about development of landscaping values determined in our study. Additionally, from the perspective of sustainable development, actions should be planned to ensure the regular upkeep of landscapes in a way that will direct and harmonize changes caused by social, economic and environmental processes (APS 2003).

The following recommendations are made for environmental development within the scope of the study area.

- Available cultural landscaping structure should be supported by sufficient esthetic and functional planting designs (Stoiljković, Grozdanović and Stanković 2020; Kelkit, 2002; Şahin and Aşkın, 2020).

- Care and maintenance work for the riverbed should be included in the program and sustainability should be ensured (Kelkit, 2003).

- Unearned income values should be taxed on a legal basis and the obtained income should be evaluated within the scope of landscaping structure outgoings

- Priority and importance should be given to public will in planning and design.

- Multiple party administration forms should be chosen

- The style of approach of real estate agents toward clients should be linked to certain standards, without bias based on local or foreign, rich or poor.

- Economic valuation of environmental features was found to be effective on attainability of housing

- Green space, view and location parameters were positively reflected in housing prices (Liang, Lee and Yong, 2020).

- The increase in housing value makes improvement in the well-being of the individual (Zhang and Zhang, 2019).

- One of the most important indicators of quality of life, the well planned housing and its surroundings increases user satisfaction.

\section{Acknowledgments}

This study was supported by the Commission of Scientific Research Projects of Çanakkale Onsekiz Mart University within the scope of Project FHD-2020-3097. For their support, I would like to express my thanks to Çanakkale Onsekiz Mart University, Scientific Research Projects Unit.

\section{References}

1. Alas B. (2020). A multilevel analysis of housing submarkets defned by the municipal boundaries and by the street connections in the metropolitan area: Istanbul. Journal of Housing and the Built Environment. https://doi.org/10.1007/s10901-020-09735-7

2. Alkan Gökler, L. (2017). Examining House Price Differentiation in Ankara Using Hedonic Analysis. Megaron, 12(2): 304-315, DOI: 10.5505/MEGARON.2017.35582 (In Turkish)

3. Alkan, Y., Uslu, C., (2016). The effects of active green spaces on houses prices: the case of Yenișehir district of Mersin province. İnönü University Journal of Art and Design, 6 (13); 1-10. (In Turkish)

4. Alphan, H. (2017). Analysis of landscape changes as an indicator for environmental monitoring. Environ Monit Assess (2017) 189: 24 DOI 10.1007/s10661-016-5748-7

5. Altan T. (2004). "Towards a More Comprehensive Landscape Architecture". TMMOB Chamber of Landscape Architects Publication. Ankara. (In Turkish)

6. APS (2003). Law on The Ratification of the European Landscaping Convention, Law No: 4881, Date of Acceptance: 10.06.2003 Official Newspaper Date: 2003-06-17, Official Number of Newspapers: 2514. (In Turkish)

7. Bican, N., B. (2019). Public mass housing practices in Turkey: the urgent need for research-based spatial decision-making. Journal of Housing and the Built Environment https://doi.org/10.1007/s10901-019-09692W 1

8. Chen, Z., Xu, B., Devereux, B. (2015). Assessing public aesthetic preferences towards some urban landscape patterns: the case study of two different geographic groups. Environ Monit Assess (2016) 188: 4 DOI 10.1007/s10661-015-5007-3

9. Czischke, D., Bortel, G. (2018). An exploration of concepts and polices on 'affordable housing' in England, Italy, Poland and The Netherlands. J Hous and the Built Environ https://doi.org/10.1007/s10901018-9598-1 
10. Çelik, D. (2018). Limited Responsible Nüve Residential Building Cooperative Landscape Project. Journal of Bartin Faculty of Forestry, 20 (3): 409-419. https://dergipark.org.tr/tr/pub/barofd/issue/38873/461131 (In Turkish)

11. Demircan, K., Oğuztimur S. (2019). Literature Survey Regarding with the Affects of Metro Lines On House Prices Megaron, 14(3):417-431 DOI: 10.14744/MEGARON.2019.04875 (In Turkish)

12. François, D. R., Marius, T., Yan, K., Paul, V. (2002). Landscaping and house values: an empirical investigation. Journal of Real Estate Research, 23(1-2), 139-162.

13. Ergöz Karahan, E. (2017). Sustainability of Traditional and Contemporary Housing and Household Lifestyles: Case of Osmaneli. Megaron, 12(3): 497-510 DOI: 10.5505/MEGARON. 2017.27037 (In Turkish)

14. Freeman, A.M. (1979), "Hedonic Prices, Property Values and Measuring Environmental Benefits: A Survey of the Issues", The Scandinavian Journal of Economics, 81(2): 154-173.

15. Gefenaite, G., Björk, J., Schmidt, S. M., Slaug, B., \& Iwarsson, S. (2020). Associations among housing accessibility, housing-related control beliefs and independence in activities of daily living: a cross-sectional study among younger old in Sweden. Journal of Housing and the Built Environment, 1-11. https://doi.org/10.1007/s10901-019-09717-4

16. Goodman, A. C., Thibodeau, T. G. (2003). Housing market segmentation and hedonic prediction accuracy. Journal of Housing Economics, 12(3), 181-201.

17. Gouda, A.A. \& Masoumi, H.E. (2018). Compactness, connectivity, and walking accessibility on the neighborhood level according to sustainability certifications: improvement or downgrade? A case study of Cairo, Egypt. J Geogr Syst 20, 413-449. https://doi.org/10.1007/s10109-018-0272-7

18. Gür, M., Murat, D., Sezer, F.Ş. (2019). The efect of housing and neighborhood satisfaction on perception of happiness in Bursa, Turkey. Journal of Housing and the Built Environment. https://doi.org/10.1007/s10901-019-09708-5 1

19. Gürlük, S., Rehber, E., (2009). A study of the environmental valuation of Lake Manyas. Journal of Agricultural Economics, 15 (1); 9-15. (In Turkish)

20. Hewings, G., Nazara, S., Dridi, C. (2004). Channels of synthesis forty years on: integrated analysis of spatial economic systems. J Geograph Syst 6, 7-25. https://doi.org/10.1007/s10109-003-0120-1

21. Hur, M., Morrow-Jones, H. (2008). Factors that influence residents' satisfaction with neighbourhoods. Environment \& Behavior 40 (5): 619-635.

22. Kelkit A. (2002). A Research on Plant Material Used in Open-Green Areas, Canakkale City. Ecology Environmental Journal, 10(43): 17-21. (In Turkish)

23. Kelkit A. (2003). Environmental problems of Canakkale City and solutions. International Journal of Environment and Pollution, 19(1): 66-74.

24. Kyttä, M., Kahila, M., Broberg, A. (2011). Perceived environmental quality as an input to urban infill policy-making. Urban Des Int 16, 19-35. https://doi.org/10.1057/udi.2010.19

25. Liang, C.M., Lee, C.C., Yong, L.R. (2020). Impacts of urban renewal on neighborhood housing prices: predicting response to psychological efects. Journal of Housing and the Built Environment (2020) 35:191213 https://doi.org/10.1007/s10901-019-09673-z

26. Likert, R. (1932-1933). A Technique fort he measurement of attitudes, archives of psychology, 22, USA.

27. Makinde, O.O. (2013). Housing delivery system, need and demand. Retrieved February 2014, from Journal of Environment, Development and Sustainability: DOI 10.1007/s10668-013-9474-9

28. Mínguez, R., Montero, J. M., Fernández-Avilés, G. (2013). Measuring the impact of pollution on property prices in Madrid: objective versus subjective pollution indicators in spatial models. Journal of Geographical Systems, 15(2), 169-191. https://doi.org/10.1007/s10109-012-0168-X

29. Montero, Jm., Mínguez, R. \& Fernández-Avilés, G. (2018). Housing price prediction: parametric versus semi-parametric spatial hedonic models. J Geogr Syst 20, 27-55. https://doi.org/10.1007/s10109-017-0257y

30. Montero-Lorenzo, Jm., Larraz-Iribas, B., Páez, A. (2009). Estimating commercial property prices: an application of cokriging with housing prices as ancillary information. Journal of Geographical Systems, 11(4), 407. https://doi.org/10.1007/s10109-009-0095-7

31. Mukhtar, M. M., Amirudin, R. B., Sofield, T., Mohamad, I. B. (2017). Critical success factors for public housing projects in developing countries: a case study of Nigeria. Environment, Development And Sustainability, 19(5), 2039-2067. https://doi.org/10.1007/s10668-016-9843-2

32. Nayim, B. (2014). Determination of physically suitable areas for residential settlement with LUCIS model, Bartin city example. Journal of Bartin Faculty of Forestry, 16(23): 44-58. Retrieved from. https://dergipark.org.tr/tr/pub/barofd/issue/15841/178813 (In Turkish)

33. Olanrewaju, A., Wong, H. C. (2020). Evaluation of the requirements of frst time buyers in the purchase of afordable housing in Malaysia. Journal of Housing and the Built Environment (2020) 35:309-333 https://doi.org/10.1007/s10901-019-09681-z 
34. Ozkan, U.Y. (2014). Assessment of visual landscape quality using IKONOS imagery. Environ Monit Assess (2014) 186:4067-4080 DOI 10.1007/s10661-014-3681-1

35. Payaslı Ŏguz G., Aksulu, I., B. (2016). Traditional Houses of Bitlis: Conservation Issues and Suggestions. Megaron, 11(1): 63-77 DOI: 10.5505/MEGARON.2016.76588 (In Turkish)

36. Pulido, A., 1972. Estadistica y Tecnicas de Investipacion Sosial. Ediciones Anaya, Madrid.

37. Qiu, L., Tu, Y., Zhao, D. (2019). Information asymmetry and anchoring in the housing market: a stochastic frontier approach. Journal of Housing and the Built Environment https://doi.org/10.1007/s10901-01909701-y 1

38. Rimal, B., Keshtkar, H., Sharma, R., Stork, N., Rijal, S. \& Kunwar, R. (2019). Rimal, B., Keshtkar, H., Sharma, R., Stork, N., Rijal, S., \& Kunwar, R. (2019). Simulating urban expansion in a rapidly changing landscape in eastern Tarai, Nepal. Environmental Monitoring And Assessment, 191(4), 1-14. https://doi.org/10.1007/s10661-019-7389-0

39. Salihoğlu, T., Türkoğlu, H. (2019). Residential Environment and Quality of Urban Life. Megaron, 14 (SUPPL. 1): 203-217 DOI: 10.5505/MEGARON.2018.06977 (In Turkish)

40. Sarı, B.Ö., Khurami, E.A. (2018). Housing affordability trends and challenges in the Turkish case. Journal of Housing and the Built Environment, 1-20. https://doi.org/10.1007/s10901-018-9617-2 1

41. Scharer, C., Baranzini, A., Ramirez, J. V., Thalmann, P. (2008). Using the hedonic approach to value natural land uses in an urban area: application to Geneva and Zurich. Economie Publique $=$ Public economics, (20), 1-23.

42. Soguel, N., Tangerini, A., Pictet, J. (2007). How to measure scope variables when no metrics exist: Application to landscape quality measurement and hedonic price evaluation. Revue D'économie Politique, $117(5), 827-841$.

43. Soguel, N., Martin, M. J., Tangerini, A. (2008). The impact of housing market segmentation between tourists and residents on the hedonic price for landscape quality. Swiss Journal of Economics and Statistics, 144(4), 655-678. https://doi.org/10.1007/BF03399270

44. Stoiljković, B., Grozdanović, N. P., Stanković, V. (2020). Could house-like apartments improve the residential quality of a city? The case of Niš, Serbia. Journal of Housing and the Built Environment (2020) 35:375-396 https://doi.org/10.1007/s10901-019-09687-7

45. Şahin, C. \& Aşkın, M. (2020). A Study on Investigation of Apartment Gardens in Isparta City Center. Journal of Bartin Faculty of Forestry, 22 (2), 319-331. DOI: 10.24011/barofd.706049 (In Turkish)

46. Turcotte, D. A., Geiser, K. (2010). A framework to guide sustainable housing development. Housing and Society, 37(2), 87-117.

47. Turk, S. (2019). Private fnance integration to afordable housing production: a comparison between Copenhagen and Istanbul. Journal of Housing and the Built Environment https://doi.org/10.1007/s10901-018-09643-x 1

48. Vlahov, D., Agarwal, S.R., Buckley, R.M. et Al. (2011). Vlahov, D., Agarwal, S.R., Buckley, R.M., Caiaffa, W.T., Corvalan, C.F., Ezeh, A.C., ... , Watson, V.J. (2011). Roundtable on urban living environment research (RULER). Journal of Urban Health, 88(5), 793-857. https://doi.org/10.1007/s11524011-9613-2

49. Willis, K., Garrod, G., (1991). An individual travel-cost method of evaluating forest recreation. Journal of Agricultural Economics, 42(1), 33-42. https://doi.org/10.1111/j.1477-9552.1991.tb00330.x

50. Wong, S., Y., Susilawati, C., Miller, W., Mardiasmo, D. (2020). Perspectives of Australian property practitioners on sustainability features in residential property. Journal of Housing and the Built Environment https://doi.org/10.1007/s10901-019-09726-3 13

51. Yao, Y., Zhu, X., Xu, Y., Yang, H., Wu, X., Li, Y. \& Zhang, Y. (2012). Assessing the visual quality of green landscaping in rural residential areas: the case of Changzhou, China. Environmental Monitoring and Assessment, 184:951-967. https://doi.org/10.1007/s10661-011-2012-Z

52. Yılmaz, F., Koç, A.A. (2018). Determination of the economic value of Beydaglar Coast National Park with travel cost and conditional valuation methods. Mediterranean I.I.B.F. Journal. 38: 1-22. (In Turkish)

53. Zhang, C., Zhang, F. (2019). Efects of housing wealth on subjective well-being in urban China. Journal of Housing and the Built Environment. 34:965-985 https://doi.org/10.1007/s10901-019-09651-5

54.Zhang, Z., Qiu, Z. (2019). The usage pattern and spatial preference of community facilities by elder people in rural environments. Journal of Housing and the Built Environment https://doi.org/10.1007/s10901-019$\underline{09707-61}$ 